\title{
JUURNAL.RU
}

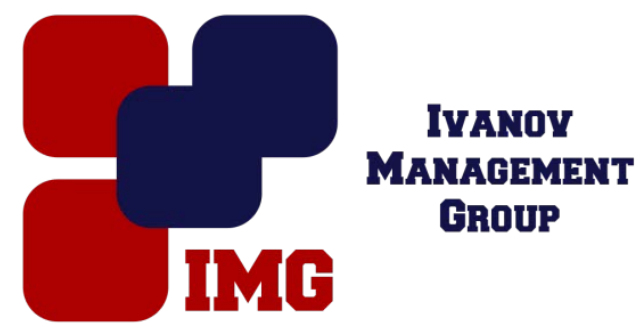

Лорсанов Ш.И. Южно-Российский государственный политехнический Университет имени М. И. Платова Новочеркасск, Россия

doi: 10.18411/lj-25-12-2016-1-05

idsp 000001:lj-25-12-2016-1-05

\section{Добавки для цементных бетонов}

Развитие промышленности строительных материалов связаны с необходимостью разработки новых ресурсо- и энергосберегающих технологий, в т.ч. получение различных видов цементных бетонов гидратационного твердения с повышенными эксплуатационными характеристиками и долговечностью. Данная проблема может быть решена оптимизацией структуры цементного камня-бетона высокоактивными нанодисперсными добавками (НД). Эффективным решением этого вопроса по производству доступных по стоимости НД является активация природного и техногенного силикатного (опал-кристобалитовые породы, биогенный кремнезем, микрокремнезем, золы уноса, отвальные золошлаковые смеси, отсевы дробления бетонного лома и др.), углерод-силикатного (шунгитовые породы) или алюмосиликатного сырья. В качестве альтернативы многим силикатным нанодисперсным добавкам, в производстве быстротвердеющих и высокопрочных цементных бетонов применяются алюмосиликатные НД, получаемые из глин и продуктов их обработки, одним из них являются метакаолин, который обладает высокой пуццоланической активностью. На рис.1 предоставлено распределение по размерам частиц метакаолина до ультразвукового диспергирования.

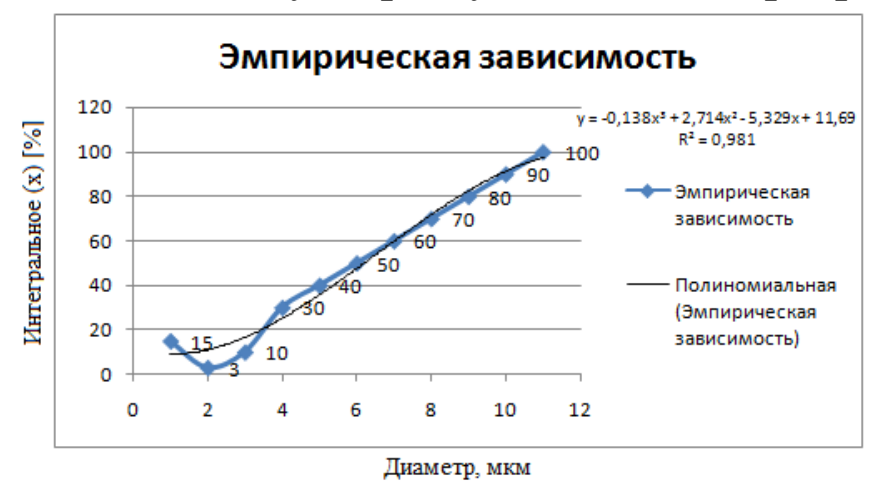

Рисунок 1. Распределение по размерам частии метакаолина доультразвукового диспергирования. 
Ультразвуковое диспергирование метакаолина в водных средах органических стабилизаторов осуществляли по методике, изложенной в работе.

Результаты растровой электронной микроскопии (РЭМ) на приборе TESCAN MIRA 3 LMU показали, что структура метакаолина до УЗД представлена наличием отдельных крупнодисперсных частиц и их агрегатов.

Ультразвуковое диспергирование метакаолина в водных средах используемых стабилизаторов способствует эрозии его микрочастиц и агрегатов вплоть до нанодиапазона, а также расщеплению нанотолщинных гексагональных пластинок, содержащихся в столбчатых конгломератах (рисунок 2).

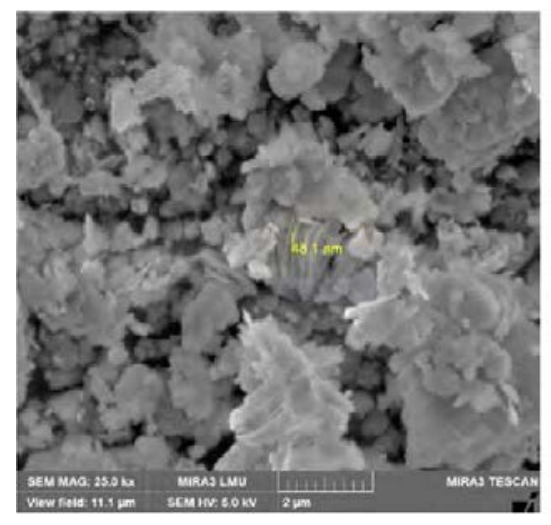

a)

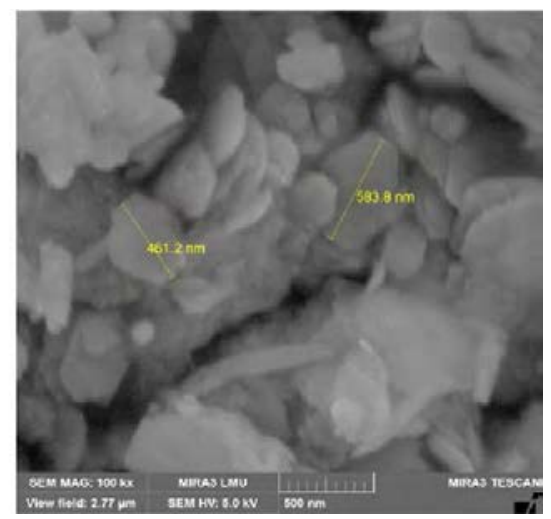

б)

Рисунок 2 - Структура частиц метакаолина: а-исходного (× 25000); б - после ультразвукового диспергирования (× 100000)

Выполненные исследования позволяют сделать следующие выводы:

1. Обоснована возможность получения агрегативно-устойчивых нанодисперсных добавок для цементных бетонов способом ультразвукового диспергирования метакаолина в водных средах органических стабилизаторов анионного и неионогенного типов: суперпластификатора С-3 и поливинилового спирта.

2. Выявлено, что эффект стабилизации С-3 вызван, главным образом, тем, что адсорбционные слои повышают абсолютную величину $\zeta-$ потенциала частиц метакаолина, то есть агрегативная устойчивость обеспечивается преимущественно их электростатическим отталкиванием.

3. Разработанные нанодисперсные добавки оказывают направленное воздействие на формирование структуры цементного камня за счет дополнительного образования цементного геля, низкоосновных гидросиликатов кальция и гидроалюминатов кальция, способствующих перераспределению пористости системы в сторону уменьшения объема микропор и увеличения объема нанопор диаметром менее 100 нм (в 5-7 раз), что существенно повышает прочность цементного камня (на 121-152 \% в зависимости от вида добавки). 


\section{Литература}

1. Фаликман, В.Р. Наноматериалы и нанотехнологии в строительстве: сегодня и завтра / В.Р. Фаликман // Строительные материалы, оборудование, технологии ХХІ века. - 2009. - № 1. - С. 64-67.

2. Фиговский, О.Л. Успехи применения нанотехнологий в строительных материалах / О.Л. Фиговский, Д.А. Бейлин, А.Н. Пономарев // Нанотехнологии в строительстве: научный Интернет-журнал. - 2012. - № 3. - C. 6-21.

3. Лукутцова, Н.П. Теоретические и технологические аспекты получения микро- и нанодисперсных добавок на основе шунгитосодержащих пород для бетона / Н.П. Лукутцова, А.А. Пыкин. - Брянск: БГИТА, 2014. - 216 с. 